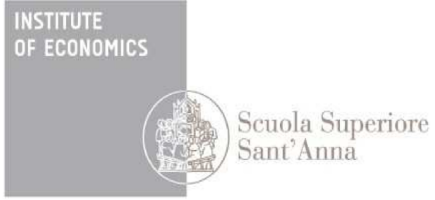

LEM | Laboratory of Economics and Management

Institute of Economics

Scuola Superiore Sant'Anna

Piazza Martiri della Libertà, 33 - 56127 Pisa, Italy ph. +3905088.33 .43$

institute.economics@sssup.it

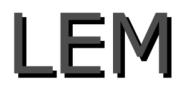

Working Paper Series

\title{
Drivers of Firm Growth: Micro-evidence from Indian Manufacturing
}

Nanditha Mathew ${ }^{\mathrm{a}}$

${ }^{a}$ Department of Economics and Management, University of Pisa, Italy 


\title{
Drivers of Firm Growth: Micro-evidence from Indian Manufacturing
}

\author{
Nanditha Mathew*
}

\begin{abstract}
The paper presents micro evidence on firm dynamics for enterprises in Indian Manufacturing sectors on the grounds of Prowess database provided by the Centre for Monitoring Indian Economy (CMIE) covering the period 1991-2010. The parameterization of the distributions of growth exhibit high level heterogeneity displayed among firms even within the same sector, which widens over time. The transition probabilities matrix reveals the coexistence of firms with very different characteristics and performance within sectors. Given the wide heterogeneities, the paper resorts to quantile regression to identify the differential effect of regressors at different deciles of the conditional distrubution.
\end{abstract}

Keywords: Firm Dynamics, AEP Distribution, Heterogeneity, Quantile Regression

\section{Introduction}

Indian economic growth for the first three decades since independence was phrased as the "Hindu rate of growth" by Raj Krishna ${ }^{1}$. The term was used disparagingly, suggesting the low growth rate of India till 1980s when compared to the other Asian countries which were newly independent ${ }^{2}$. Thanks to the economic transformation in the past two decades, the term is no more used to address the growth situation of the country. India's improved economic performance, besides being good news for its one billion people, also upholds expectations for other poor countries around the world (Rodrik and Subramanian; 2005).

The question of whether this improved aggregate performance is simply a consequence of reallocating resources from a low productivity (agriculture) sector to higher productivity (manufacturing and services) sectors, or was there an improvement in the performance

\footnotetext{
*Dipartimento di Economia e Management, Universita di Pisa. email:nandithamathew@ec.unipi.it

${ }^{1}$ Indian economist who worked at Delhi School of Economics

${ }^{2}$ The term had connotations referring to the supposed Hindu outlook of fatalism and contentedness.
} 
of individual sectors is worth addressing. The present work concentrates in detail on the performance of the manufacturing sector in India.

The process of development, including the shift from agricultural sector towards manufacturing and services, involves displacement of labour from the former. As recognised globally, the manufacturing sector is expected to create mass employment for this displaced lot. In India as well, the role of the manufacturing sector is recognised to be critical not only for facilitating large-scale employment but also for enabling high GDP growth (Virmani and Hashim; 2009).

As pointed out by many studies, the success story of India has not been based on strong growth in manufacturing (Bosworth et al.; 2007). In fact, India introduced substantial product market reforms in this sector since the mid 1980s expecting large payoffs in terms of higher growth and employment generation. The empirical evidence on the benefits and losses owing to such reforms is mixed. However, in comparison with the service sector, the growth in the manufacturing sector is not highly appreciated, especially for a developing economy like India (Bosworth et al.; 2007). Although the services sector has been growing fast, it alone cannot absorb the 250 million additional income-seekers that are expected to join the workforce in the next 15 years (Government of India; 2011).

In this background, this paper investigates the factors determining growth in the Indian manufacturing sector at a disaggregated level, by looking at the firm level dynamics behind the aggregate trend in Indian Manufacturing. First, the main feature observed from the empirical analysis is the high degree of heterogeneity displayed among firms even in the same sector which is widespread (across all sectors) and persistent (over time). The recent micro evidence from many studies had witnessed the property of heterogeneity in most of the dimensions under investigation. The models with an evolutionary perspective starting from (Nelson and Winter; 1982; Winter; 1984; Silverberg et al.; 1988; Silverberg and Verspagen; 1994; Dosi et al.; 1995; Winter et al.; 2000; Bottazzi et al.; 2001), till the recent works of Bottazzi et al. (2010) and Dosi et al. (2012) proposes heterogeneity as the driver of firm growth and industrial dynamics. In this respect, the findings of the present work also corresponds to the existing evidence by earlier literature on the property of heterogeneity, one of the most general and robust stylized facts in industrial economics.

Second, the paper identifies different 'types' of firms within the same sector employing the transition probabilities matrix. There is evidence of coexistence of different types of firms with different characteristics and performance within the same sector. These different types of firms are associated with different characteristics in terms of exporting activity, spending on R\&D and profitability. 
The existence of differently performing firms even within the same sector motivates the need to detect the possible underlying firm-level characteristics associated with their performance. Firm-level characteristics such as exporting activities and R\&D spending could provide an explanation for the differential performance across firms. In this respect, the present paper is in line with earlier literature on firm dynamics (see Dosi et al.; 2012; Bottazzi et al.; 2010) which considers the firm-level characteristics as good candidates for explanation of differences across firms.

Micro-level studies indicate that the differences in firm performance within sectors are highly correlated with their exporting activities (Roberts and Tybout; 1997; Bernard and Jensen; 1995; 1999; Bernard et al.; 2007). Several studies including Wagner (2002) observed positive relation between exporting of firms and its performance. In this respect, third, the paper examines the relation between exporting activities and firm performance and quite surprisingly, fails to find evidence of positive relation between the two. On the contrary, the results suggest that the non-exporting firms perform better in terms of growth than the exporters. As per the predictions of international trade theory, or the export-led growth hypothesis, one would expect the presence of positive correlation between export growth and economic growth, especially after the launch of substantial product market reforms in India. Haidar (2012) using similar data finds that exporters outperform non-exporters in terms of total factor productivity, capital, sales and unit labour cost before entering the export market, while there was no evidence of increase in productivity after entering the export market. However, the paper does not look at the relation between entry in the export market and growth in sales. The present paper, examines the relation between exporting activities of firms and their growth and finds that the non-exporters perform better in terms of growth compared with the exporting firms. Grazzi (2012) using Italian firm-level data finds that the exporting activity of firms are not associated with higher profitability. Bernard and Jensen (1999) finds that good performing firms turns good exporters, ex-ante, but the benefits of exporting for the firm are quite blurred.

Economic theorizing had given ample importance to the role of innovation in growth of firm sales (see Aghion and Howitt; 1992; Geroski; 2002). Empirical studies (Lichtenberg and Siegel; 1991; Hall and Mairesse; 1995) have documented the positive impact of firms' R\&D activities and its productivity. Keeping in mind the earlier literature (among others, Hall; 1987; Del Monte and Papagni; 2003; Lefebvre et al.; 1998) which identifies positive relation between R\&D and firm growth, fourth this paper also examines the impact of R\&D on firm growth. Quite surprisingly, R\&D could not be identified as a significant factor in explaining growth of firms in Indian manufacturing. 


\section{Data Description}

The paper employs firm-level data from the Prowess database, provided by the CMIE (Centre For Monitoring Indian Economy Pvt. Ltd.). The data are collected by the CMIE from company balance sheets and income statements and covers both publicly listed and unlisted firms from a wide cross-section of manufacturing, services, utilities, and financial industries. About one-third of the firms in Prowess are publicly listed firms. The companies covered account for around 70 percent of industrial output, 75 percent of corporate taxes, and more than 95 percent of excise taxes collected by the Government of India. Earlier studies, among others, Topalova and Khandelwal (2011) have used similar database to understand the impact of trade liberalization on firm productivity and Goldberg et al. (2010) to study the relationship between declines in trade costs, the imports of intermediate inputs and domestic firm product scope.

Since one of the main objectives of the paper is to understand the underlying drivers of the macro trend using micro data, the initial requirement is to verify whether the micro data is a good replication of the aggregate trend revealed from the macro data. This comparison is done by looking at the macro data provided by the Annual Survey of Industries ${ }^{3}$ and the micro data used in this paper. The variables compared are total value of output produced at aggregate level and the total value of sales of all firms, the comparison being done at both levels and growth rates for all sectors at 2-digit level. The current values of the variables are deflated with output deflators at 2-digit level. The National Industry Classification (hereafter NIC) changes three times during the period of analysis and therefore, using the concordance table, the industries are classified according to the latest available industry classifiaction. ${ }^{4}$ Figure 1 displays the time series trend of the growth rates of total value of sales of firms and total value of output for selected 2-digit sectors. The growth rates of both variables are reported in table 9 in Appendix B. ${ }^{5}$ The meagre differences between the two lines in figure 1 , represented by the micro and the macro data, confirms the potential of the micro data to replicate the properties observed in the aggregate trend. The sectors in which the micro data are unable to replicate the aggregate trend and with small number of observations are removed from the analysis and hence not reported. Therefore, the paper considers the following sectors for analysis: NIC 10, 13, 17, 20, 21, 22, 23, 24, 25, 26, 27 and $28 .{ }^{6}$

To study the factors contributing towards firm growth, the major variables considered are growth rate of the firm, profitability, research and development (hereafter R\&D) expenses

\footnotetext{
${ }^{3}$ The Annual Survey of Industries is an annual publication by the Central Statistical Organisation, Ministry of Statistics, Government of India. It is the principal source of industrial statistics in India.

${ }^{4}$ Table 10 in Appendix C demonstrates the latest classification.

${ }^{5}$ Comparison is also done in levels, the figures are available upon request.

${ }^{6}$ Refer Appendix C for NIC codes and respective classification of 2-digit sectors.
} 

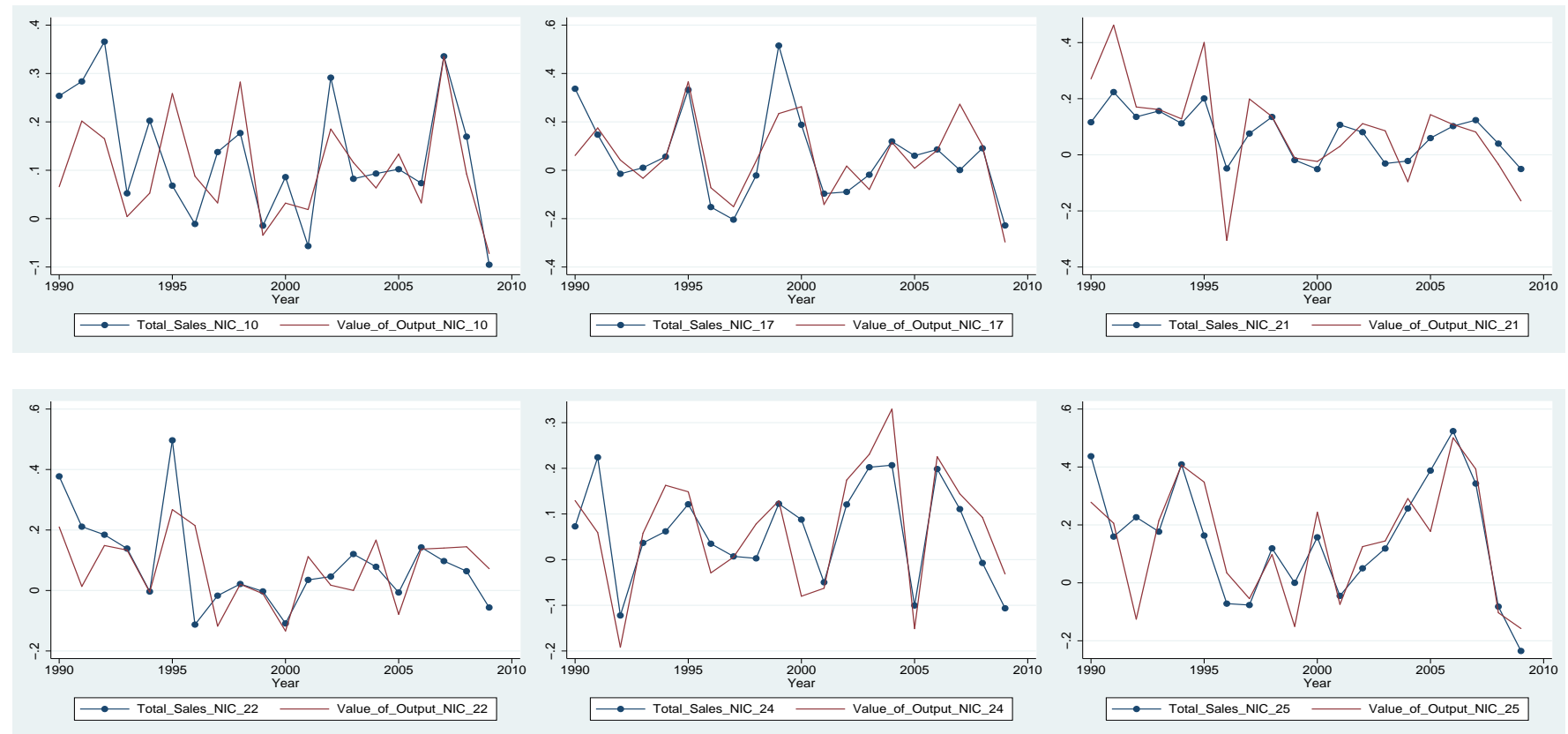

Figure 1: Growth Rates of total sales for firms and value of output (at constant 2000 prices) for sectors at 2-digit level. Top NIC 10, 17 and 21. Bottom NIC 22, 24 and 25.

and exports. The proxy for growth of the firm is the log difference of total sales ${ }^{7}$ at constant prices $^{8}$ in $t$ and $t+1$, where $t$ and $t+1$ are 3 and 2 year averages. The proxy for profitability is the ratio of gross operating margins divided by total sales. In order to account for exports, a dummy variable is considered, if the firm has exported or not in a particular year, which takes the value 1 if the firm has exported and 0 otherwise. The spending on R\&D is expected to have a positive impact in explaining growth of firms, and therefore, a dummy variable for $R \& D$ expenses is considered (which takes the value 1 if the firm is spending on $R \& D$ expenses and 0 otherwise). The time period of the study is from 1991 to 2010, which is divided into 4 sub periods, namely, 1991-93 to 1994-95, 1996-98 to 1999-00, 2001-03 to 200405 and 2006-08 to 2009-10. The beginning point and end point of each time period are three and two year averages. The four sub periods of five year each are used in order to include maximum information, here, maximum number of firms, since we are considering only the firms which exist in the beginning and end point. ${ }^{9}$

\footnotetext{
${ }^{7}$ Prowess does not provide data on number of employees and therefore sales of firms are used.

${ }^{8}$ The current values of the variables are deflated with output deflators at two digit level. The data on two digit output deflators are from the Reserve Bank of India's Handbook of Statistics on the Indian Economy.

${ }^{9} \mathrm{~A}$ longer time period would leave out the firms which enter and exit during the specific time period.
} 


\section{Intra-sectoral heterogeneity in firm growth: Some non-parametric analysis}

This section examines the distribution of firm growth, its properties and evolution over time. Recent empirical micro evidence from several countries, see for example, Duschl et al. (2011) for Germany, Bottazzi et al. (2011) for France, Reichstein and Jensen (2005) for Denmark, Bottazzi et al. (2002) for Italian manufacturing data, shows that the assumption of normal distribution of growth rates could be consistently rejected. Dosi et al. (2012) using the Italian

firm level data finds high heterogeneity in the distributions of labor productivity. In line with earlier studies, (see for example, Stanley et al.; 1996; Amaral et al.; 1997; Bottazzi and Secchi; 2006), here the focus is on the shape of the distribution of firm growth rates. Using the database on Indian manufacturing firms, the paper finds evidence of heterogeneity in the distribution of firm growth at 2-digit level of disaggregation. By looking at the kernel density distributions, it is observed that the distributions are fat-tailed, asymmetric, leptokurtic and bimodal in few cases.

In this case, one needs a more general and flexible distributional model that could describe the empirical distribution of firm growth. The Subbotin family of distributions introduced into economics by Bottazzi et al. (2002) takes the functional form:

$$
f(g ; b, a, m)=\frac{1}{2 * a * b^{\frac{1}{b}} * \Gamma\left(1+\frac{1}{b}\right)} e^{\left(-\frac{1}{b} *\left|\frac{g-m}{a}\right|^{b}\right)}
$$

with $\Gamma$ (.) for the Gamma function. The three parameters defining the distribution are:

1. $m$, the location parameter, which indicates the existence of a general trend in the data

2. $a$, the scale parameter which determines the spread or dispersion of the distribution

3. $b$, the shape parameter which indicates the shape/thickness of the tails

The normal distribution (when $b=2$ ) and Laplace (when $b=1$ ), also known as the symmetric exponential distribution are particular cases of the Subbotin family of probability densities. Therefore, this distribution family allows for a continuous variation from nonnormality to normality, with smaller values of $b$ representing fatter tails of the distribution. Bottazzi and Secchi (2011) extends this to a 5-parameter family of distributions, the Asymmetric Exponential Power (AEP) distribution which is able to cope with the asymmetries in the data. In addition to the location parameter $m$, representing the mode, the AEP has two positive scale parameters $a_{r}$ and $a_{l}$, associated with the distribution width above and below the modal value, and two positive shape parameters $b_{r}$ and $b_{l}$ describing the tail behavior 
in the right and the left tail. The AEP density presents the following functional form:

$$
\left.f_{A E P}\left(g ; b_{l}, b_{r}, a_{l}, a_{r}, m\right)=\frac{1}{C} e^{\left(-\left[\frac{1}{b_{l}} *\left|\frac{g-m}{a_{l}}\right|^{b_{l}} * \theta(m-g)+\frac{1}{b_{r}} *\left|\frac{g-m}{a_{r}}\right|^{b_{r}} * \theta(g-m)\right]\right.}\right)
$$

where $\theta(\mathrm{g})$ is the heaviside theta function and the normalization constant $\mathrm{C}=a_{l} b_{l}^{1 / b_{l}-1} \Gamma\left(1 / b_{l}\right)$ $+a_{r} b_{r}^{1 / b_{r}-1} \Gamma\left(1 / b_{r}\right)$.

Figure 2 displays the AEP with empirical and normal fit for NACE 13, 20 and 21. Here, we look at few properties of the distributions on firm growth.
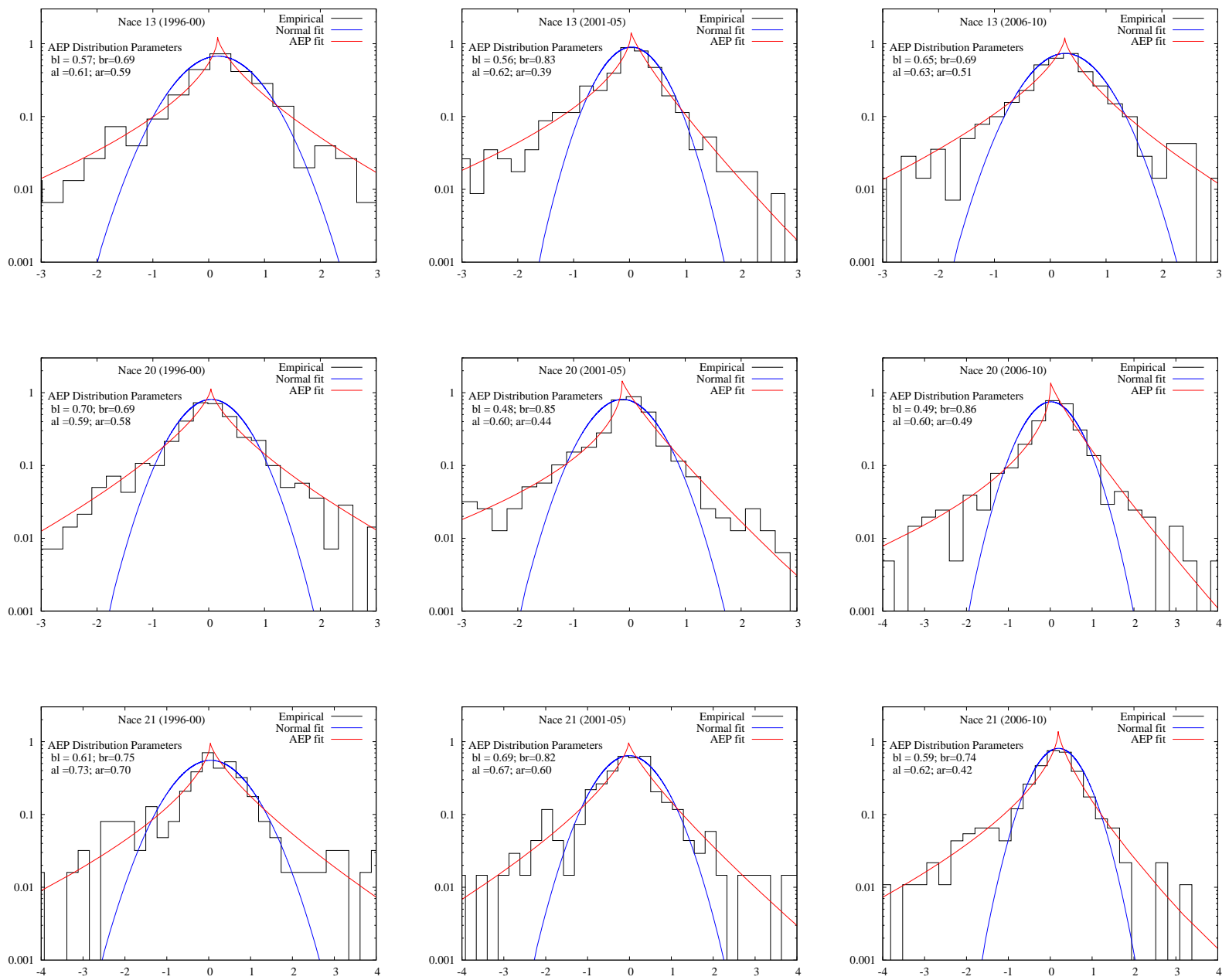

Figure 2: Empirical density of firm growth rates over five year periods, for the textiles sector (NIC 13), chemical and chemical products (NIC 20) and pharmaceuticals (NIC 21), together with normal and AEP fits. Probabilities on the y-axis are on $\log$ scale.

The evidence indicates an extremely robust stylized fact: growth rates display distributions which are at least exponential (Laplace) or even fatter in their tails. This property 
holds across (i) levels of aggregation, (ii) different sectors (iii) time. ${ }^{10}$ There is wide literature which identifies wide and persistent inter-firm asymmetries in production coefficients at all levels of disaggregation (see Baily et al.; 1992; Jensen and McGuckin; 1997; Baldwin; 1998; Bartelsman and Doms; 2000; Bottazzi et al.; 2002; Bottazzi and Secchi; 2006; Dosi; 2007).

While observing Table 1, which displays the estimated values of the $b_{l}$ and $b_{r}$ parameters, one finds that almost all values (except for a few) are less than 2, confirming the non-normal distributions. It is also worth noting that this property holds the same across sectors and across time. One could argue that the effect of the mechanisms causing the fat tails may fade away when longer time horizons are considered. Therefore, analysis using different time spans ${ }^{11}$ are performed and the shape parameter $b$ still remains lower than the normal value of 2 . The fat tails point to a large number of firms with extreme growth rates, and this is much higher than one would expect on the ground of any Guassian distribution.

The presence of fat tails in the distribution implies much more structure in the growth dynamics than generally assumed . The fat tails are an indication of some underlying mechanism, which one would rule out if the growth events were normally distributed (Dosi and Nelson; 2010).

Table 1: Estimates of the shape parameters $\left(b_{l}\right)$ and $\left(b_{r}\right)$ for the sectors under analysis

\begin{tabular}{|c|c|c|c|c|c|c|c|c|}
\hline \multirow{2}{*}{$\begin{array}{l}\text { Year } \\
\text { NIC }\end{array}$} & \multicolumn{2}{|c|}{ 1991-95 } & \multicolumn{2}{|c|}{ 1996-00 } & \multicolumn{2}{|c|}{ 2001-05 } & \multicolumn{2}{|c|}{ 2006-10 } \\
\hline & $\mathrm{bl}$ & br & $\mathrm{bl}$ & br & $\mathrm{bl}$ & br & $\mathrm{bl}$ & br \\
\hline 10 & 0.50 & 0.83 & 0.53 & 0.46 & 0.52 & 0.72 & 0.53 & 0.69 \\
\hline 13 & 0.48 & 0.76 & 0.57 & 0.69 & 0.56 & 0.83 & 0.65 & 0.68 \\
\hline 17 & 0.41 & 0.42 & 0.57 & 0.59 & 0.37 & 0.95 & 0.56 & 0.50 \\
\hline 20 & 0.73 & 0.58 & 0.70 & 0.68 & 0.48 & 0.85 & 0.49 & 0.86 \\
\hline 21 & 0.47 & 0.66 & 0.61 & 0.75 & 0.69 & 0.82 & 0.59 & 0.74 \\
\hline 22 & 0.99 & 0.86 & 0.55 & 0.68 & 0.48 & 0.85 & 0.47 & 0.82 \\
\hline 23 & 0.44 & 2.87 & 0.63 & 0.99 & 0.45 & 1.97 & 0.61 & 0.62 \\
\hline 24 & 0.57 & 0.54 & 0.48 & 1.27 & 0.52 & 0.78 & 0.61 & 0.66 \\
\hline 25 & 0.39 & 2.24 & 0.41 & 0.65 & 1.15 & 0.66 & 0.57 & 0.96 \\
\hline 26 & 0.44 & 0.64 & 0.57 & 1.14 & 0.67 & 2.05 & 0.91 & 0.58 \\
\hline 27 & 0.36 & 0.73 & 0.55 & 0.77 & 0.72 & 1.81 & 0.57 & 1.45 \\
\hline 28 & 0.37 & 0.77 & 0.71 & 0.68 & 0.63 & 1.32 & 0.59 & 1.83 \\
\hline
\end{tabular}

\footnotetext{
${ }^{10}$ The tests are also performed for 3-digit level which are not reported here. The paper restricts the analysis to 2-digit level since the number of firms is too small for some sectors in further disaggregation.

${ }^{11}$ The distribution of growth rates for five year upto ten year time-lag, which are not reported here.
} 


\section{Dynamics Over Time: Transition Probabilities Matrix}

In the previous section, it was observed that the distributions of growth of firms are fat tailed and display wide heterogeneity. Given the wide heterogeneities in the performance of firms, the transition probabilites matrix (hereafter TPM) helps in identifying the relative performance of firms over time. The TPM contains the probability values of firms being in the particular state (quartile, in the present case) and this allows to observe the persistence in the performance of firms. Here, persistence means the probability of remaining in the state in which the firm initially is, where the state is defined on the basis of growth of firms. The transition probabilities matrices are computed for each sector and for the 4 sub-periods under analysis.

Dosi et al. (2012) and Bartelsman and Dhrymes (1998) focusing on the distributions on productivity, finds persistence in the relative performance of firms. Here, with the distributions on firm growth, the paper observes low persistence in firm growth. Given high heterogeneity, one might expect persisting differences also in firm growth rates, but this is not confirmed by this empirical data.

Table 2 reports the transition probabilities matrices over the period 2006-10 for selected sectors. Growth at time $t$ is defined as the logarithmic differences of sales between 2006 and 2008 and in $t+1$ as the difference between 2009 and 2010. The transition probabilities matrices in table 2, report low probabilities along the main diagonal, suggesting that the probability that the firm stays in the initial state is lower. It is also noticeable that the less persistence of the matices are evident in all sectors. Transition probabilities matrices for the rest of the sub periods of 5 year interval each also shows similar results.

\subsection{Different group of firms and their characteristics}

With the help of TPM, the paper identifies different groups of firms. Table 3 gives the definition of the different group of firms in the transition matrix. This classification is adopted from Dosi et al. (2012). The firms that are persistently in the bottom of the distribution at both $t$ and $t+1$ are the 'growth laggards', those that have successfully jumped to the top in $t+1$, the 'growth climbers' and those that are persistently at the top of the distribution, the 'growth leaders'. 
Table 2: Transition Probabilities Matrices between time $t$ (growth rate between 2006 and 08) and $t+1$ (growth rate between 2009 and 10) for the distribution of firm growth

\begin{tabular}{|c|c|c|c|c|c|c|c|c|c|c|c|}
\hline \multirow[t]{2}{*}{ NIC 10} & & \multicolumn{4}{|l|}{$\mathrm{t}+1$} & \multirow[t]{2}{*}{ NIC 13} & & \multicolumn{4}{|l|}{$\mathrm{t}+1$} \\
\hline & & 1 & 2 & 3 & 4 & & & 1 & 2 & 3 & 4 \\
\hline \multirow[t]{4}{*}{$\mathrm{t}$} & 1 & 27.84 & 22.78 & 22.78 & 26.58 & $\mathrm{t}$ & 1 & 31.76 & 21.17 & 12.94 & 34.11 \\
\hline & 2 & 18.75 & 25.00 & 27.50 & 28.75 & & 2 & 28.23 & 30.58 & 29.41 & 11.76 \\
\hline & 3 & 23.75 & 28.75 & 30.00 & 17.50 & & 3 & 23.52 & 22.35 & 29.41 & 24.70 \\
\hline & 4 & 29.11 & 24.054 & 20.25 & 26.58 & & 4 & 16.47 & 25.88 & 28.23 & 29.41 \\
\hline \multirow[t]{2}{*}{ NIC 17} & & $\mathrm{t}+1$ & & & & NIC 20 & & $\mathrm{t}+1$ & & & \\
\hline & & 1 & 2 & 3 & 4 & & & 1 & 2 & 3 & 4 \\
\hline \multirow[t]{4}{*}{$\mathrm{t}$} & 1 & 28.00 & 28.00 & 24.00 & 20.00 & $\mathrm{t}$ & 1 & 27.72 & 18.81 & 19.80 & 33.66 \\
\hline & 2 & 30.77 & 23.08 & 23.09 & 23.00 & & 2 & 28.71 & 30.69 & 26.73 & 13.86 \\
\hline & 3 & 19.23 & 30.77 & 19.23 & 30.07 & & 3 & 24.75 & 23.76 & 30.69 & 20.79 \\
\hline & 4 & 20.00 & 20.00 & 36.00 & 24.00 & & 4 & 18.81 & 26.73 & 22.77 & 31.68 \\
\hline \multirow[t]{2}{*}{ NIC 21} & & $\mathrm{t}+1$ & & & & NIC 22 & & $\mathrm{t}+1$ & & & \\
\hline & & 1 & 2 & 3 & 4 & & & 1 & 2 & 3 & 4 \\
\hline \multirow[t]{4}{*}{$\mathrm{t}$} & 1 & 33.33 & 13.72 & 27.45 & 25.09 & $\mathrm{t}$ & 1 & 30.00 & 28.00 & 22.00 & 20.00 \\
\hline & 2 & 17.30 & 42.30 & 19.23 & 21.15 & & 2 & 18.36 & 28.57 & 28.57 & 24.48 \\
\hline & 3 & 25.49 & 25.49 & 35.29 & 13.72 & & 3 & 24.00 & 20.00 & 34.00 & 22.00 \\
\hline & 4 & 23.52 & 19.60 & 17.64 & 39.21 & & 4 & 26.00 & 22.00 & 16.00 & 36.00 \\
\hline \multirow[t]{2}{*}{ NIC 23} & & $\mathrm{t}+1$ & & & & NIC 24 & & $t+1$ & & & \\
\hline & & 1 & 2 & 3 & 4 & & & 1 & 2 & 3 & 4 \\
\hline \multirow[t]{4}{*}{$\mathrm{t}$} & 1 & 34.48 & 17.24 & 20.68 & 27.58 & $\mathrm{t}$ & 1 & 27.90 & 18.60 & 24.41 & 29.06 \\
\hline & 2 & 20.00 & 26.66 & 26.66 & 26.66 & & 2 & 28.73 & 28.73 & 22.98 & 19.40 \\
\hline & 3 & 16.66 & 26.66 & 33.33 & 23.33 & & 3 & 18.39 & 31.03 & 32.18 & 18.40 \\
\hline & 4 & 27.58 & 31.03 & 20.68 & 20.68 & & 4 & 24.41 & 22.09 & 20.93 & 32.55 \\
\hline \multirow[t]{2}{*}{ NIC 25} & & $\mathrm{t}+1$ & & & & NIC 26 & & $\mathrm{t}+1$ & & & \\
\hline & & 1 & 2 & 3 & 4 & & & 1 & 2 & 3 & 4 \\
\hline \multirow[t]{4}{*}{$\mathrm{t}$} & 1 & 28.00 & 12.00 & 24.00 & 36.000 & $\mathrm{t}$ & 1 & 37.50 & 12.50 & 16.66 & 33.33 \\
\hline & 2 & 32.00 & 28.00 & 32.00 & 80.00 & & 2 & 20.00 & 36.00 & 24.00 & 20.00 \\
\hline & 3 & 20.00 & 32.00 & 28.00 & 20.00 & & 3 & 20.00 & 28.00 & 44.00 & 80.00 \\
\hline & 4 & 20.00 & 28.00 & 16.00 & 36.00 & & 4 & 20.83 & 25.00 & 16.662 & 37.50 \\
\hline \multirow[t]{2}{*}{ NIC 27} & & $\mathrm{t}+1$ & & & & NIC 28 & & $\mathrm{t}+1$ & & & \\
\hline & & 1 & 2 & 3 & 4 & & & 1 & 2 & 3 & 4 \\
\hline \multirow[t]{4}{*}{$\mathrm{t}$} & 1 & 30.00 & 25.00 & 22.25 & 22.25 & $\mathrm{t}$ & 1 & 19.14 & 29.78 & 14.89 & 36.17 \\
\hline & 2 & 26.82 & 21.95 & 24.39 & 26.82 & & 2 & 23.40 & 25.53 & 34.04 & 17.020 \\
\hline & 3 & 97.56 & 26.82 & 41.46 & 21.95 & & 3 & 25.53 & 23.40 & 27.65 & 23.40 \\
\hline & 4 & 31.70 & 26.82 & 12.19 & 29.26 & & 4 & 31.91 & 21.27 & 23.40 & 23.40 \\
\hline
\end{tabular}


Table 3: Definition of Growth laggards (A), climbers (B) and leaders (C)

\begin{tabular}{cccccc}
\multicolumn{6}{c}{$t+1$} \\
& & 1 & 2 & 3 & 4 \\
& & & & & \\
\hline & 1 & $\mathrm{~A}$ & $\mathrm{~A}$ & & $\mathrm{~B}$ \\
& & & & \\
& & $\mathrm{~A}$ & $\mathrm{~A}$ & & $\mathrm{~B}$ \\
& 3 & & & & \\
& 4 & & & & $\mathrm{C}$ \\
\hline
\end{tabular}

The paper examines the various characteristics of these different categories of firms identified with the help of the transition probabilities matrix. Table 4 reports for a selection of 2-digit sectors, the characteristics of growth laggards, climbers and leaders at the beginning of the sub period 2006-10.

The characteristics of different group of firms in terms of profitability, exporting activities $^{12}$ and decision to spend on $\mathrm{R} \& \mathrm{D}^{13}$ are observed. Firstly, concerning profits, mostly, it is seen that the growth leaders and climbers are more profitable than the laggards. However, the results are rather mixed for the last sub period as seen in table 4 . For few sectors, namely food, textiles, pharmaceuticals, rubber and plastics, non-metallic minerals, basic metals and computer, electronic and optical products (NIC 10, 13, 21, 22, 23, 24 and 26), the leaders and climbers are more profitable than laggards. For other few sectors, namely, paper and paper products, chemicals, fabricated metal products, electrical equipment and machinery and equipment (NIC 17, 20, 25, 27 and 28). In the third sub-period, only in two sectors, namely, non-metallic mineral products and basic metals, the laggards are more profitable than climbers and leaders. In the second sub-period, only for the pharmaceuticals sector, the laggards are more profitable than the leaders, while in the first sub-period, for two sectors, namely, other non-metallic mineral products and machinery and equipment, the laggards are better than the leaders and climbers ${ }^{14}$. With the exception of the above said, in general, the leaders and climbers are more profitable than the laggards.

Secondly, concerning firms' decision to undertake R\&D activities, mostly it is observed that the growth laggards undertake more $R \& D$ activities than leaders and climbers with some exceptions. As stated in table 4, in the fourth sub-period, in most of the sectors

\footnotetext{
${ }^{12}$ The dummy for exporting activities takes value 1 if the firm is exporting and 0 otherwise.

${ }^{13}$ The dummy for R\&D takes value 1 if the firm is exporting and 0 otherwise.

${ }^{14}$ The characteristics of different group of firms for the fourth sub period are shown in the paper. For the previous three sub periods, the figures are available upon request
} 
under analysis, the growth laggards undertake more R\&D activities except for four sectors, namely, manufacture of rubber and plasctics, other non-metallic mineral products, computer, electronic and optical products and electrical equipment (NIC 22, 23, 26 and 27). In these sectors, the laggards undertake more R\&D activities than leaders. However, the climbers are on an average, carry out more R\&D activities than the other two categories. In the previous sub periods too, the trend is that the growth laggards engage more in R\&D activities. The exceptions to this are, in the first sub period, manufacture of rubber and plastics, other non-metallic mineral products and computer, electronic and optical products (NIC 22, 23 and 26), in the second sub period, manufacture of food and computer, electronic and optical products (NIC 10 and 26), and in the third sub period, manufacture of food, rubber and plastics, other non-metallic mineral products and computer, electronic and optical products (NIC 10, 22, 23 and 26).

Thirdly, and the most puzzling evidence is the difference among different group of firms in terms of exporting activity. It is seen that the growth laggards are better exporters than growth climbers and leaders across all sub periods and all sectors with few exceptions. The exceptions are, in the fourth sub-period, three sectors, namely, food sector, electrical equipment and manufacture of machinery and equipment, in the third sub-period, three sectors, namely, food sector, rubber and plastics and computer, electronic and optical products, in the second sub-period, food sector, other non-metallic mineral products and electrical equipment and in the first sub-period, food sector and fabricated metal products. Keeping apart these exceptions, in all other sectors in all sub-periods, the growth laggards are better exporters than leaders and climbers.

In the previous section, we found evidence of heterogeneous firms existing within the same sector. The TPM reveals the co-existence of different "types" of firms associated with differential performance and characteristics like exporting and R\&D activities. The higher association of exporting and $\mathrm{R} \& \mathrm{D}$ activities with the less performers on an average raises doubts on the benefits reaped by firms from such activities. 
Table 4: Characteristics of Growth Laggards, Climbers and Leaders for the sub period 2006-10. Averages and standard deviations (in brackets).

\begin{tabular}{|c|c|c|c|c|c|c|}
\hline Variable & $\begin{array}{l}\text { Laggards } \\
\text { Avg (std) }\end{array}$ & $\begin{array}{l}\text { Climbers } \\
\text { Avg (std) }\end{array}$ & $\begin{array}{l}\text { Leaders } \\
\text { Avg (std) }\end{array}$ & $\begin{array}{l}\text { Laggards } \\
\text { Avg (std) }\end{array}$ & $\begin{array}{l}\text { Climbers } \\
\text { Avg (std) }\end{array}$ & $\begin{array}{l}\text { Leaders } \\
\text { Avg (std) }\end{array}$ \\
\hline & Sector 10 & & & Sector 13 & & \\
\hline Profit & $-0.0009(0.159)$ & $-0.042(0.292)$ & $-0.454(1.753)$ & $-0.104(1.507)$ & $0.779(5.431)$ & $5.288(25.369)$ \\
\hline $\mathrm{R} \& \mathrm{D}$ & $0.169(0.352)$ & $0.159(0.356)$ & $0.048(0.218)$ & $0.102(0.292)$ & $0.051(0.195)$ & $0.080(0.277)$ \\
\hline Export & $0.360(0.458)$ & $0.469(0.473)$ & $0.460(0.499)$ & $0.568(0.481)$ & $0.440(0.472)$ & $0.533(0.481)$ \\
\hline Obs & $\begin{array}{l}75 \\
\text { Sector } 17\end{array}$ & 44 & 21 & $\begin{array}{l}95 \\
\text { Sector } 20\end{array}$ & 39 & 25 \\
\hline Profit & $0.216(1.085)$ & $-0.009(0.145)$ & $0.017(0.009)$ & $-0.167(4.702)$ & $-0.588(2.390)$ & $0.901(4.940)$ \\
\hline $\mathrm{R} \& \mathrm{D}$ & $0.238(0.424)$ & $0.090(0.301)$ & $0.000(0.000)$ & $0.349(0.463)$ & $0.285(0.413)$ & $0.302(0.426)$ \\
\hline Exports & $0.298(0.409)$ & $0.212(0.402)$ & $0.166(0.408)$ & $0.598(0.477)$ & $0.524(0.494)$ & $0.563(0.467)$ \\
\hline Obs & $\begin{array}{l}28 \\
\text { Sector } 21\end{array}$ & 11 & 6 & $\begin{array}{l}108 \\
\text { Sector } \mathbf{2 2}\end{array}$ & 48 & 32 \\
\hline Profit & $-1.346(7.814)$ & $0.184(0.791)$ & $0.249(0.956)$ & $-0.701(0.408)$ & $-0.001(0.193)$ & $200.002(847.048)$ \\
\hline$R \& D$ & $0.448(0.481)$ & $0.264(0.393)$ & $0.317(0.452)$ & $0.169(0.336)$ & $0.182(0.395)$ & $0.129(0.326)$ \\
\hline Exports & $0.654(0.453)$ & $0.500(0.491)$ & $0.616(0.462)$ & $0.503(0.473)$ & $0.485(0.501)$ & $0.481(0.460)$ \\
\hline Obs & $\begin{array}{l}55 \\
\text { Sector } 23\end{array}$ & 24 & 20 & $\begin{array}{l}52 \\
\text { Sector } 24\end{array}$ & 22 & 18 \\
\hline $\begin{array}{l}\text { Profit } \\
\text { R\&D }\end{array}$ & $\begin{array}{l}0.034(0.119) \\
0.287(0.452)\end{array}$ & $\begin{array}{l}0.144(0.543) \\
0.313(0.479)\end{array}$ & $\begin{array}{l}1.895(4.146) \\
0.167(0.408)\end{array}$ & $\begin{array}{l}0.008(0.262) \\
0.119(0.301)\end{array}$ & $\begin{array}{l}0.059(0.077) \\
0.087(0.256)\end{array}$ & $\begin{array}{l}0.050(0.125) \\
0.083(0.266)\end{array}$ \\
\hline Exports & $0.529(0.484)$ & $0.500(0.516)$ & $0.277(0.389)$ & $0.528(0.452)$ & $0.373(0.455)$ & $0.440(0.435)$ \\
\hline Obs & $\begin{array}{l}29 \\
\text { Sector } 25\end{array}$ & 16 & 6 & $\begin{array}{l}90 \\
\text { Sector } 26\end{array}$ & 42 & 28 \\
\hline Profit & $0.069(0.164)$ & $0.211(0.847)$ & $0.017(0.187)$ & $-0.793(3.452)$ & $-0.076(0.344)$ & $-0.376(2.162)$ \\
\hline $\mathrm{R} \& \mathrm{D}$ & $0.120(0.332)$ & $0.000(0.000)$ & $0.000(0.000)$ & $0.321(0.447)$ & $0.513(0.464)$ & $0.222(0.441)$ \\
\hline Exports & $0.600(0.481)$ & $0.273(0.467)$ & $0.518(0.444)$ & $0.647(0.448)$ & $0.487(0.502)$ & $0.519(0.503)$ \\
\hline Obs & $\begin{array}{l}25 \\
\text { Sector } 27\end{array}$ & 11 & 9 & $\begin{array}{l}26 \\
\text { Sector } \mathbf{2 8}\end{array}$ & 13 & 9 \\
\hline Profit & $0.032(0.848)$ & $-0.042(0.307)$ & $-0.529(1.496)$ & $0.102(0.355)$ & $5.130(25.477)$ & $0.016(0.287)$ \\
\hline $\mathrm{R} \& \mathrm{D}$ & $0.175(0.369)$ & $0.433(0.473)$ & $0.167(0.389)$ & $0.399(0.469)$ & $0.200(0.385)$ & $0.242(0.397)$ \\
\hline Exports & $0.452(0.458)$ & $0.716(0.408)$ & $0.388(0.489)$ & $0.645(0.468)$ & $0.707(0.412)$ & $0.576(0.496)$ \\
\hline Obs & 42 & 20 & 12 & 46 & 25 & 11 \\
\hline
\end{tabular}




\section{Determinants of Growth}

The analysis from the previous section raises questions on the firm level characteristics which determines the growth of firms over time. This section tries to identify the factors determining firm growth starting with a simple cross-sectional regression model: ${ }^{15}$

$$
\Delta y_{t, t+1}=\alpha+\beta_{1} P f t_{i, t}+\beta_{2} \operatorname{Exp}_{i, t}+\beta_{3} R \& D_{i, t}+\beta_{4} Z_{i, t}+\epsilon_{i}
$$

where $\Delta y_{t, t+1}$ represents firm growth, ie, log differences of sales between time $t$ and $t+1$. As mentioned earlier in the paper, the analysis is performed for 4 sub periods, ${ }^{16} 1991-95$, 1996-2000, 2001-05 and 2006-10. The beginning of each sub period, ie, $t$, is the average of each variable for the first 3 years (1991-1993, 1996-98, 2001-03 and 2006-08) and for $t+1$, the average of the last 2 years (1994-95, 1999-00, 2004-05 and 2009-10) respectively.

The independent variables considered are profitability, export dummy and R\&D dummy at time $t$. Profitability $\left(P f t_{i, t}\right)$ is defined by the ratio of profits over sales. Export dummy $\left(\operatorname{Exp}_{i, t}\right)$ takes the value 1 if the firm was exporting in any one of the first 3 years. ${ }^{17} \mathrm{R} \& \mathrm{D}$ dummy takes the value 1 if the firm has spend on R\&D in any of the first 3 years. ${ }^{18}$ The control variables in order to control for the firm-level characteristics at time $t$, are represented by the vector $\left(Z_{i, t}\right)$, which includes, the initial size of the firm and regional dummies. ${ }^{19}$

Table 5 reports the OLS estimates for the sectors under analysis for the last sub period, 2006-10. The coefficient values at 5 percent and 1 percent level of significance are in bold. The OLS estimates for previous sub periods are reported in Appendix A. In the first sub period, as seen in table 6, profitability is significant in nine sectors, and the coefficient is positive in seven sectors, implying that higher profitability in the initial period leads to higher growth in the coming years. The sectors are manufacture of food, textiles, chemicals, rubber and plastics, non-metallic minerals, electrical equipments and machinery and equipment (NIC 10, 13, 20, 22, 23, 27 and 28). Two sectors, namely, paper and paper products and fabricated metal products (NIC 17 and 25), report negative coefficient values indicating negative relation between profitability and firm growth. In the second sub period, as seen in table 7, except for one sector (manufacture of electrical equipments, (NIC 27)), profitability has significant

\footnotetext{
${ }^{15}$ Cross sectional regression has the advantage of reducing endogeneity problems between the dependent and independent variables.

${ }^{16}$ The selection of shorter time period also allows one to include more number of firms since only the firms which stays in the market in beginning and the end period are considered.

${ }^{17}$ In the present sample, if the firm exports in the first year, in more than $90 \%$ of the cases, it exports in the next two years as well.

${ }^{18}$ Here, we use the dummy and not the ratio of $R \& D$ over sales to avoid the endogeneity between $R \& D$ and the dependent variable.

${ }^{19}$ Dummy takes each value for each state.
} 
Table 5: OLS estimates of growth regression for the sub period 2006-10. Standard errors are given in brackets.

\begin{tabular}{|c|c|c|c|c|c|c|}
\hline & NIC 10 & NIC 13 & NIC 17 & NIC20 & $\mathrm{NIC} 21$ & NIC22 \\
\hline \multirow[t]{2}{*}{ Profitability } & 0.002 & $0.018^{* * *}$ & -0.001 & $0.007^{* * *}$ & $0.033^{* * *}$ & $-0.0005^{* *}$ \\
\hline & $(0.011)$ & $(0.005)$ & $(0.006)$ & $(0.002)$ & $(0.008)$ & $(0.0002)$ \\
\hline \multirow[t]{2}{*}{ Export Dummy } & 0.0564 & $0.208^{* * *}$ & 0.061 & 0.058 & $0.272^{* *}$ & 0.079 \\
\hline & $(0.086)$ & $(0.086)$ & $(0.187)$ & $(0.089)$ & $(0.114)$ & $(0.108)$ \\
\hline \multirow[t]{2}{*}{$\mathrm{R} \& \mathrm{D}$} & 0.017 & 0.066 & 0.041 & 0.009 & 0.084 & -0.051 \\
\hline & $(0.125)$ & $(0.152)$ & $(0.244)$ & $(0.097)$ & $(0.118)$ & $(0.153)$ \\
\hline Observations & 527 & 492 & 153 & 596 & 313 & 295 \\
\hline \multirow[t]{2}{*}{$R$-squared } & 0.003 & 0.054 & 0.002 & 0.038 & 0.090 & 0.021 \\
\hline & NIC 23 & NIC 24 & NIC 25 & NIC26 & $\mathrm{NIC} 27$ & NIC 28 \\
\hline \multirow[t]{2}{*}{ Profitability } & $0.071^{*}$ & $-0.010 * * *$ & 0.011 & -0.001 & -0.001 & $-0.008^{*}$ \\
\hline & $(0.042)$ & $(0.000)$ & $(0.017)$ & $(0.003)$ & $(0.003)$ & $(0.004)$ \\
\hline \multirow[t]{2}{*}{ Export Dummy } & -0.167 & 0.126 & $-0.296^{* *}$ & -0.169 & $0.354^{* *}$ & 0.131 \\
\hline & $(0.126)$ & $(0.081)$ & $(0.144)$ & $(0.185)$ & $(0.136)$ & $(0.098)$ \\
\hline \multirow[t]{2}{*}{$\mathrm{R} \& \mathrm{D}$} & 0.098 & -0.118 & 0.109 & 0.280 & -0.065 & -0.004 \\
\hline & $(0.148)$ & $(0.149)$ & $(0.287)$ & $(0.199)$ & $(0.159)$ & $(0.098)$ \\
\hline Observations & 176 & 507 & 159 & 166 & 250 & 275 \\
\hline$R$-squared & 0.024 & 0.192 & 0.029 & 0.019 & 0.034 & 0.002 \\
\hline
\end{tabular}

*** Significant at a level of $1 \%, * *$ Significant at a level of $5 \%,{ }^{*}$ Significant at a level of $10 \%$

impact in explaining growth. ${ }^{20}$ The firms with higher profitability registered higher growth for 6 sectors, namely, manufacture of textiles, chemicals, rubber and plastics, non-mettalic minerals, fabricated metals and machinery (NIC 13, 20, 22, 23, 25 and 28), while for another 5 sectors, namely, manufacture of food, textiles, paper and paper products, pharmaceuticals, basic metals and computer and electronics (NIC 10, 13, 17, 21, 24 and 26), higher profitability is associated with lower growth.

In the third sub period, as seen in table 8, profitability was significant in explaining growth for seven sectors and the impact was positive for 5 sectors, namely, manufacture of paper and paper products, chemicals, pharmaceuticals, rubber and plastics and fabricated metals (NIC 17, 20, 21, 22 and 25). The sectors, manufacture of food and non-metallic mineral products (NIC 10 and 23) witnessed negative impact of profitability on growth. In the last sub period,

\footnotetext{
${ }^{20}$ NIC 13 and 28 significant at 10 percent level, rest all significant at 5 percent level.
} 
as seen in table 5 where profitability explains firm growth significantly in seven sectors, firms that are profitable in the intial years reports higher growth for four sectors, namely the sector on manufacture of textiles, chemicals, pharmaceuticals and non-metallic mineral products (NIC 13, 20, 21 and 23). The result is opposite to few other sectors namely, manufacture of rubber and plastics (NIC 22), basic metals (NIC 24) and machinery and eqipment (NIC 28) where higher profitability in the initial period is associated with lower growth.

Concerning firms' decision to undertake exporting activities, the exporting activities of firms are not related to its growth in any of the sectors, in the first sub period (see table 6 in Appendix A). This is true also for the second sub period (see table 7 in Appendix A), with the exception of one sector (NIC 10), where the exporting activities of firms in the initial years are associated with lower growth in the coming years. In the third sub period, as seen in table 8, export dummy is significant for 2 sectors, namely, manufacture of paper and paper products and chemicals (NIC 17 and 20). Among these, firms which undertake more exporting activities reports lower growth for the NIC 17 (paper and paper products), while for the chemicals sector, the effect is positive, implying that the firms which are active exporters register higher growth. As documented in Table 5, in the last sub period, the export dummy is significant for four sectors; the impact being positive for only 3 sectors, namely, manufacture of textiles, pharmaceuticals and electrical equipments (NIC 13, 21 and 27). For the fabricated metals sector (NIC 25), the firms which are more engaged in exports register lower growth in the coming years.

Concerning R\&D expenses, it is quite puzzling that not even in one sector, the decision to spend on R\&D is associated with firm growth. Firms' decision to spend on R\&D is not related to its growth in any of the sectors and in any of the sub periods. ${ }^{21}$

So far, in this section, cross sectional regressions were used for the analysis. We observed earlier, that there exists different 'types' of firms with different levels of performance in terms of growth, and their characteristics differ for each groups. This leaves room to believe that the impact and significance of the independent variables (export, $R \& D$ and profitability) might differ at different points (deciles) of the distribution of growth. ${ }^{22}$ Therefore, a quantile regression analysis is performed in order to detect the differential influence of the independent variables at different deciles of the distribution of growth.

\subsection{Quantile regression analysis}

The previous section, examines the determinants of firm growth by using Ordinary Least Squares (OLS) estimation. Here, the interest is in the relationship between firm growth (prox-

\footnotetext{
${ }^{21} \mathrm{R} \& \mathrm{D}$ is significant only for sector 22 (Manufacture of Rubber and Plastics) for the second sub period.

${ }^{22}$ In section 3 of this paper, we saw that the distributions were non-normal, assymetric and displayed heterogeneity.
} 
ied by log differences of sales) on one hand, and a set of firm-level characteristics (exports, profitability, R\&D) on the other. However, examining this relationship using OLS leaves no room for firm heterogeneity. In the earlier part of the paper, we already witnessed that the distribution of the firm growth displayed wide heterogneities. Ordinary Least Squares (OLS) assumes that the conditional distribution of firm growth is homogenous given the set of firmspecific characteristics. This would imply that on all points of the conditional distribution analysed, the estimates of the relationship between firm growth (dependent variable) and the firm-level characteristics (independent variables) are the same. Here as mentioned earlier, due to the significant heterogeneities in the distribution of firm growth, there is ample reason to believe that the effect of the regressors differs at different deciles of the dependent variable. In contrast to OLS (which gives information on the effects of the regressors at the conditional mean of the dependent variable), quantile regression can provide parameter estimates at different quantiles.
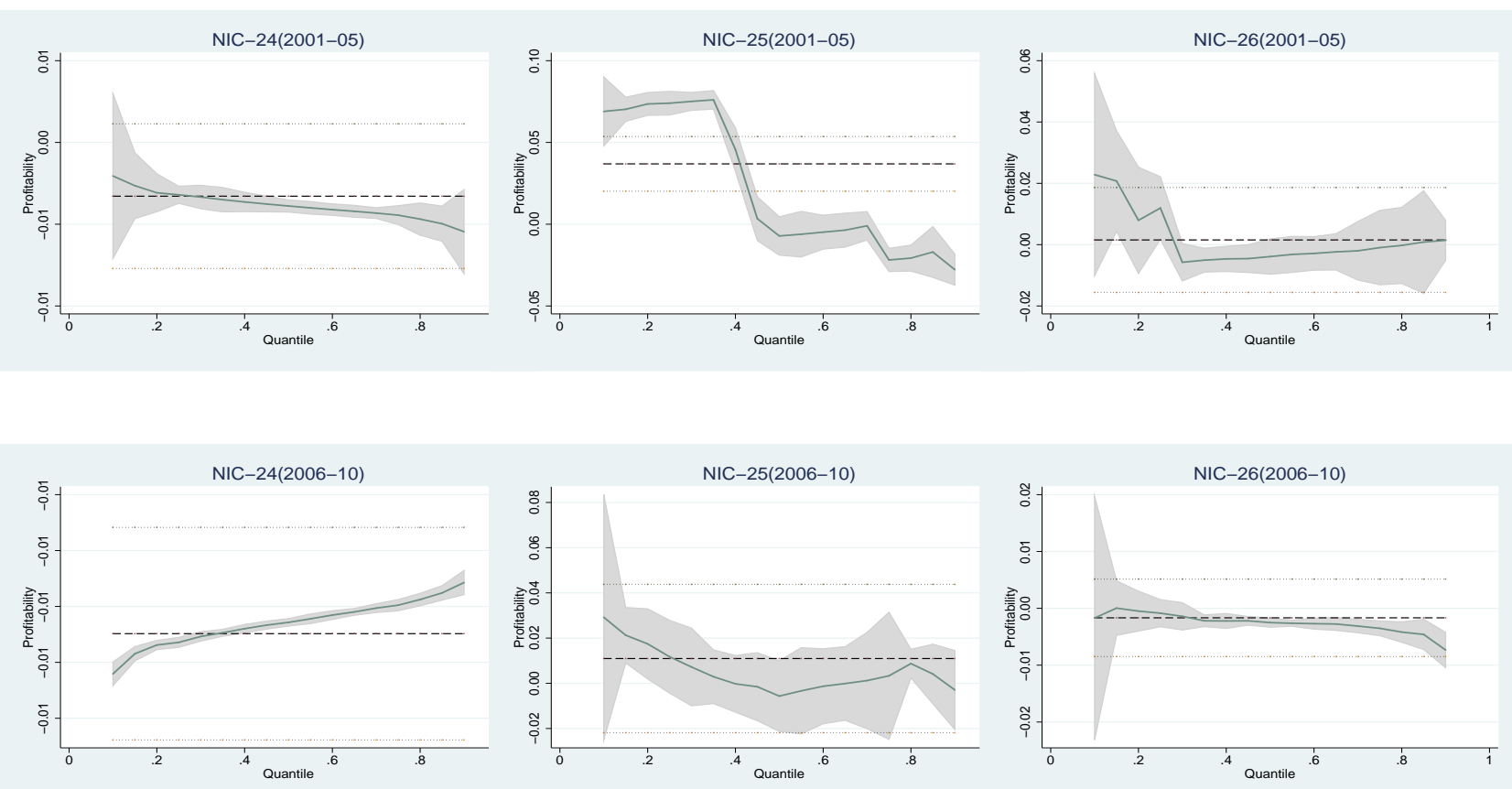

Figure 3: Quantile regression estimates. Top The relation between profitability and firm growth in the third sub period, 2001-05. Bottom The relation between profitability and firm growth in the fourth sub period, 2006-10.

In this section, we refine the analysis by performing quantile regression which helps in observing the different impact of the independent variables on the dependent variable (firm growth in the present case) at different quantiles. ${ }^{23}$

\footnotetext{
${ }^{23}$ Discussion on the technical details of quantile regression are beyond the scope of the paper. For technical introduction refer to (Koenker and Basset; 1978) and for a non-technical introduction refer to (Koenker and Hallock; 2001)
} 
Figure 3 and figure 4 displays the quantile regression estimates for selected sectors for the last 2 sub periods. The OLS estimates are represented by the flat dashed lines with the confidence interval on either sides. The line crossing the flat line are the quantile regression estimates with shaded area on both sides representing its confidence intervals. The estimates and the statistical significance of the estimated coefficients differ across regressions for different quantiles, compared to the benchmark results from the OLS regression. The trend seen in these plots cannot be detected by employing OLS. Moreover, with the OLS results, it was rather hard to observe and interpret similar results across sectors and over time. On the contrary, using the quantile regression estimates, it is possible to observe a general trend across sectors and time.

Concerning profitability, as seen in figure 3, it is observed that the positive association between profitability and growth of firms is lower in the higher deciles of the distribution in most of the cases 24 , although such difference is not always significant.
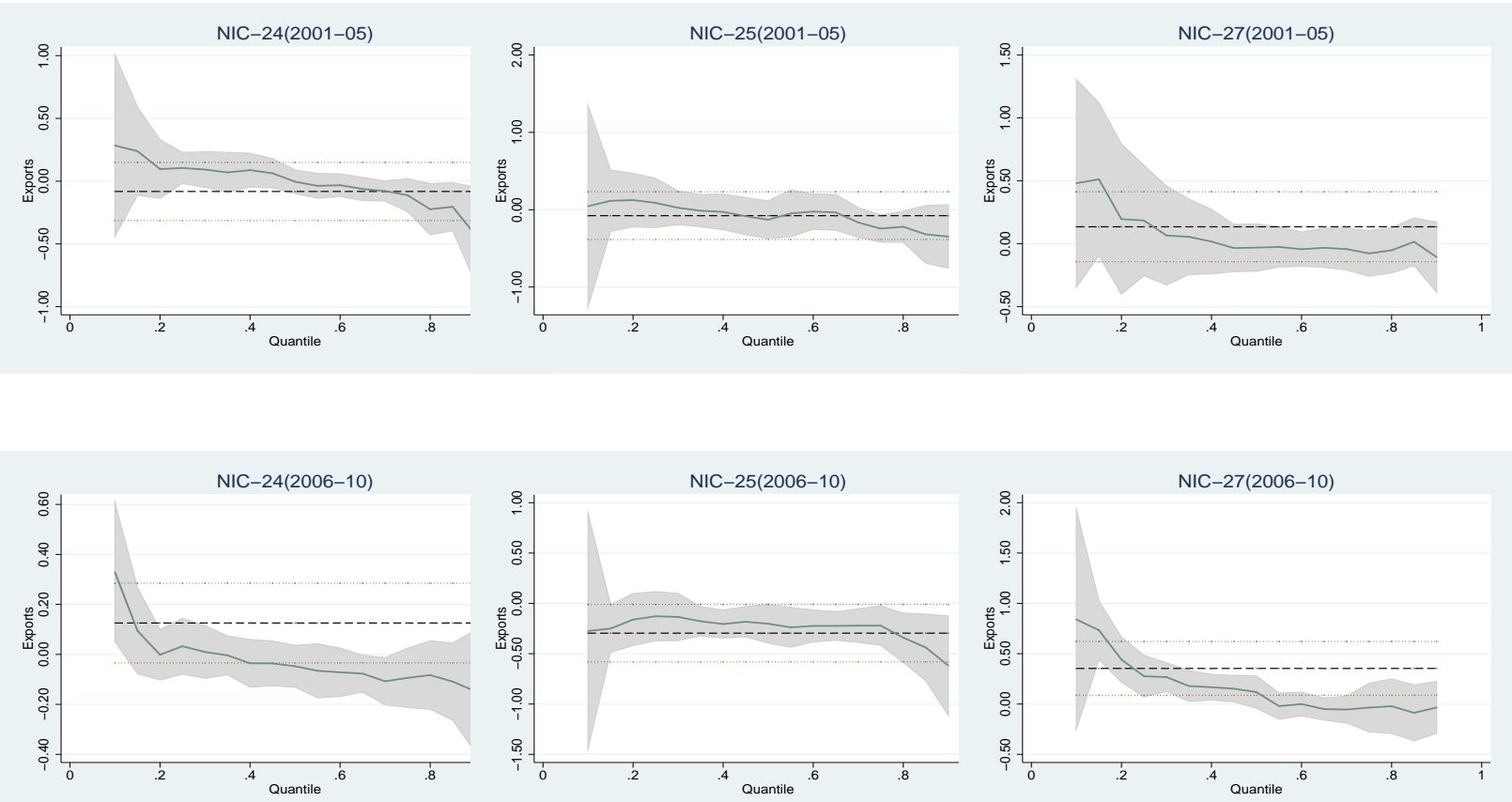

Figure 4: Quantile regression estimates. Top The relation between exports and firm growth in the third sub period, 2001-05. Bottom The relation between exports and firm growth in the fourth sub period, 2006-10.

Concerning exports, as seen in figure 4, exporting activity is not associated with higher growth of firms, especially in the higher declies of the distribution. In all sectors and in all sub periods, the graph is declining, i.e, the value of coefficients reduces towards the higher deciles of the distribution. In some cases, the variable is not significantly different from zero in the

\footnotetext{
${ }^{24}$ Exceptions are NIC 25 in the first sub period, NIC 28 in the first and second sub period and 24 in the fourth sub period.
} 
higher deciles, suggesting that exports are not significant for growth in the higher deciles of the distribution. In few sectors, as seen in figure 4 , the value of the coefficient is negative after the third or the fourth decile and this negative value increases towards the higher deciles. Taking into consideration the above results and evidence, it is quite comfortable to conclude that firms undertaking more exporting activities in the initial years are not able to reap the benefits from exporting, or, in other words, they do not observe increased growth in the following years.

Regarding firms' decision to spend on $\mathrm{R} \& \mathrm{D}$, this variable is not significant in explaining firm growth in the higher deciles of the distribution in any of the sectors. However, it is significant and positive in few sectors in the lower deciles. The sectors which witnessed positive impact of R\&D in growth are food and fabricated metals (NIC 10 and 25) in the first sub period, non-metallic minerals (NIC 23) in the last sub period and chemicals (NIC 20 ) in the last three sub periods. Quite shockingly, for basic metals sector (NIC 25), in the third sub period, R\&D is negatively related to growth of firms, especially in the higher quantiles of the distribution.

\section{Conclusions}

The micro evidence presented in this work tries to understand the dynamics behind the aggregate trend in Indian manufacturing. In line with previous literature, the present work supports the robust stylized fact on widespread and persistent heterogeneity among firms displayed in terms of growth. This paper is the first to document widespread heterogeneity in firm growth in Indian manufacturing. The intra-distributional dynamics reveals the co-existence of different 'types' of firms associated with diverse characteristics in terms of exporting activities, decision to undertake research activities etc.

Concerning the relationship between exporting activities of firms and its growth, it is rather puzzling that the exporters are not able to reap the benefits of exporting. Even though profitability is positively related to growth, this association is weaker for the 'good performers' compared to 'bad performers'. Unlike previous literature which identifies R\&D as an important factor for firm growth, among others, Hall (1987) for US manufacturing, Del Monte and Papagni (2003) for Italian manufacturing, Lefebvre et al. (1998) for small firms in Canada, the present work, employing Indian micro data, could not find evidence for the same. This raises doubts on the extent to which R\&D efforts lead to the development of new products or the ability of the firm to build knowledge to generate inventions. 


\section{Acknowledgements}

I express my sincere gratitude to Dr. Marco Grazzi for the detailed and constructive suggestions during all stages of research which contributed substantially for the paper. I thank Prof. Giovanni Dosi for the remarks and helpful comments. I am grateful to the library staff of Jawaharlal Nehru University and Delhi School of Economics. I also thank the participants of ENEF conference, Bologna 2012 and IT\&FA conference, Pisa 2012 for their comments and suggestions. Any mistake is my own responsibility.

\section{Appendix A. Regression Results for first three sub periods.}

Table 6: OLS estimates of growth regression for the sub period 1991-95. Standard errors are given in brackets.

\begin{tabular}{|c|c|c|c|c|c|c|}
\hline & NIC 10 & NIC 13 & NIC 17 & NIC20 & NIC21 & NIC22 \\
\hline \multirow[t]{2}{*}{ Profitability } & $0.421 * * *$ & $0.214^{* * *}$ & $-0.107^{* *}$ & $0.141^{* * *}$ & -0.074 & $0.041^{* * *}$ \\
\hline & $(0.771)$ & $(0.043)$ & $(0.038)$ & $(0.016)$ & $(0.115)$ & $(0.006)$ \\
\hline \multirow[t]{2}{*}{ Export Dummy } & -0.020 & -0.114 & 0.009 & -0.126 & -0.242 & -0.188 \\
\hline & $(0.098)$ & $(0.112)$ & $(0.215)$ & $(0.088)$ & $(0.206)$ & $(0.143)$ \\
\hline \multirow[t]{2}{*}{$\mathrm{R} \& \mathrm{D}$} & 0.231 & -0.008 & 0.017 & -0.134 & -0.116 & -0.301 \\
\hline & $(0.264)$ & $(0.327)$ & $(0.421)$ & $(0.163)$ & $(0.291)$ & $(0.248)$ \\
\hline Observations & 255 & 296 & 70 & 394 & 140 & 139 \\
\hline \multirow[t]{2}{*}{$R$-squared } & 0.114 & 0.081 & 0.112 & 0.179 & 0.029 & 0.254 \\
\hline & NIC 23 & NIC 24 & NIC 25 & $\mathrm{NIC} 26$ & $\mathrm{NIC} 27$ & NIC 28 \\
\hline \multirow[t]{2}{*}{ Profitability } & $0.112 * * *$ & 0.034 & $-0.015^{* * *}$ & 0.012 & $0.033^{* * *}$ & $0.303^{* * *}$ \\
\hline & $(0.022)$ & $(0.030)$ & $(0.002)$ & $(0.029)$ & $(0.008)$ & $(0.038)$ \\
\hline \multirow[t]{2}{*}{ Export Dummy } & -0.218 & -0.096 & -0.642 & -0.087 & -0.101 & -0.160 \\
\hline & $(0.177)$ & $(0.174)$ & $(0.313)$ & $(0.159)$ & $(0.101)$ & $(0.136)$ \\
\hline \multirow[t]{2}{*}{$\mathrm{R} \& \mathrm{D}$} & -0.396 & 0.147 & 1.032 & 0.106 & -0.009 & -0.053 \\
\hline & $(0.433)$ & $(0.359)$ & $(0.903)$ & $(0.264)$ & $(0.163)$ & $(0.233)$ \\
\hline Observations & 140 & 273 & 56 & 104 & 147 & 186 \\
\hline$R$-squared & 0.169 & 0.006 & 0.416 & 0.010 & 0.011 & 0.268 \\
\hline
\end{tabular}

*** Significant at a level of $1 \%, * *$ Significant at a level of $5 \%$, Significant at a level of $10 \%$ 
Table 7: OLS estimates of growth regression for the sub period 1996-00. Standard errors are given in brackets.

\begin{tabular}{lllllll}
\hline & NIC 10 & NIC 13 & NIC 17 & NIC20 & NIC21 & NIC22 \\
\hline Profitability & $\mathbf{- 0 . 0 7 4 * * *}$ & $0.014^{* *}$ & $\mathbf{- 0 . 0 0 1} * * *$ & $0.173^{* * *}$ & $\mathbf{- 0 . 0 8 5 * * *}$ & $\mathbf{0 . 3 4 4 * * *}$ \\
& $(0.017)$ & $(0.007)$ & $(0.000)$ & $(0.028)$ & $(0.015)$ & $(0.050)$ \\
Export Dummy & $\mathbf{- 0 . 5 4 0}$ & -0.027 & $0.408^{* *}$ & -0.118 & 0.035 & 0.004 \\
& $(0.127)$ & $(0.123)$ & $(0.225)$ & $(0.091)$ & $(0.174)$ & $(0.143)$ \\
R\&D & 0.255 & 0.114 & -0.070 & 0.152 & 0.141 & -0.349 \\
& $(0.174)$ & $(0.202)$ & $(0.299)$ & $(0.106)$ & $(0.177)$ & $(0.204)$ \\
Observations & 442 & 437 & 124 & 585 & 258 & 257 \\
$R$-squared & 0.085 & 0.008 & 0.056 & 0.069 & 0.110 & 0.173 \\
\hline & & & & & & \\
& NIC 23 & NIC 24 & NIC 25 & NIC26 & NIC27 & NIC 28 \\
\hline Profitability & $\mathbf{0 . 2 2 9 * * *}$ & $-\mathbf{0 . 0 1 3}$ *** & $\mathbf{0 . 0 2 6} * * *$ & $-\mathbf{0 . 0 1 6}$ *** & -0.049 & $0.021^{* *}$ \\
& $(0.050)$ & $(0.003)$ & $(0.005)$ & $(0.006)$ & $(0.037)$ & $(0.011)$ \\
Export Dummy & 0.260 & 0.241 & -0.0007 & -0.150 & -0.104 & -0.091 \\
& $(0.167)$ & $(0.155)$ & $(0.249)$ & $(0.227)$ & $(0.168)$ & $(0.113)$ \\
R\&D & 0.108 & -0.078 & 0.678 & -0.118 & 0.054 & 0.049 \\
& $(0.187)$ & $(0.225)$ & $(0.478)$ & $(0.246)$ & $(0.170)$ & $(0.120)$ \\
Observations & 163 & 349 & 116 & 157 & 203 & 236 \\
$R$-squared & 0.137 & 0.060 & 0.200 & 0.046 & 0.012 & 0.016 \\
\hline
\end{tabular}

*** Significant at a level of $1 \%,{ }^{* *}$ Significant at a level of $5 \%, *$ Significant at a level of $10 \%$

Table 8: OLS estimates of growth regression for the sub period 2001-05. Standard errors are given in brackets.

\begin{tabular}{lllllll}
\hline & NIC 10 & NIC 13 & NIC 17 & NIC20 & NIC21 & NIC22 \\
\hline Profitability & $\mathbf{- 0 . 0 1 5 * * *}$ & 0.0008 & $\mathbf{0 . 0 8 5}^{* * *}$ & $\mathbf{0 . 0 0 3}^{* * *}$ & $\mathbf{0 . 0 2 8}^{* * *}$ & $\mathbf{0 . 1 1 3}^{* * *}$ \\
& $(0.005)$ & $(0.004)$ & $(0.034)$ & $(0.001)$ & $(0.004)$ & $(0.033)$ \\
Export Dummy & -0.102 & 0.132 & $-0.427^{* *}$ & $0.146^{* *}$ & 0.045 & 0.154 \\
& $(0.087)$ & $(0.845)$ & $(0.216)$ & $(0.084)$ & $(0.113)$ & $(0.096)$ \\
R\&D & 0.034 & 0.082 & 0.314 & 0.037 & 0.068 & -0.179 \\
& $(0.119)$ & $(0.144)$ & $(0.324)$ & $(0.097)$ & $(0.122)$ & $(0.140)$ \\
Observations & 561 & 532 & 161 & 673 & 310 & 303 \\
$R$-squared & 0.018 & 0.010 & 0.069 & 0.019 & 0.124 & 0.050 \\
\hline & & & & & & \\
& NIC 23 & NIC 24 & NIC 25 & NIC26 & NIC27 & NIC 28 \\
\hline Profitability & $-\mathbf{0 . 0 6 0}$ *** & -0.003 & $\mathbf{0 . 0 3 6 * * *}$ & 0.001 & 0.096 & 0.0006 \\
& $(0.025)$ & $(0.002)$ & $(0.008)$ & $(0.008)$ & $(0.075)$ & $(0.004)$ \\
Export Dummy & 0.205 & -0.082 & -0.077 & 0.212 & 0.135 & 0.214 \\
& $(0.138)$ & $(0.117)$ & $(0.156)$ & $(0.199)$ & $(0.141)$ & $(0.127)$ \\
R\&D & 0.059 & -0.295 & -0.102 & -0.179 & -0.175 & 0.016 \\
& $(0.175)$ & $(0.203)$ & $(0.366)$ & $(0.214)$ & $(0.164)$ & $(0.131)$ \\
Observations & 178 & 464 & 155 & 185 & 256 & 282 \\
$R$-squared & 0.041 & 0.012 & 0.113 & 0.009 & 0.013 & 0.011 \\
\hline
\end{tabular}

*** Significant at a level of $1 \%, * *$ Significant at a level of $5 \%,{ }^{*}$ Significant at a level of $10 \%$ 


\section{Appendix B. Micro and macro data (growth rates)}

Table 9 presents the growth rates of total sales of all firms and output produced for sectors at 2-digit level.

Table 9: Growth Rates of total sales for all firms and output produced (both at constant 2000 prices) and for sectors at 2-digit level (in brackets).

\begin{tabular}{lllllll}
\hline Year & NIC10 & NIC13 & NIC17 & NIC20 & NIC21 & NIC22 \\
\hline $1990-91$ & $0.253(0.066)$ & $0.235(-0.248)$ & $0.336(0.061)$ & $0.146(0.105)$ & $0.116(0.271)$ & $0.210(0.183)$ \\
$1991-92$ & $0.283(0.201)$ & $0.158(1.325)$ & $0.147(0.175)$ & $0.236(0.123)$ & $0.223(0.462)$ & $0.211(0.013)$ \\
$1992-93$ & $0.365(0.165)$ & $0.032(0.048)$ & $-0.014(0.042)$ & $0.040(0.009)$ & $0.223(0.170)$ & $0.211(0.013)$ \\
$1993-94$ & $0.052(0.004)$ & $0.270(0.408)$ & $0.010(-0.033)$ & $0.076(0.244)$ & $0.156(0.161)$ & $0.138(0.134)$ \\
$1994-95$ & $0.202(0.053)$ & $0.225(-0.026)$ & $0.056(0.050)$ & $0.119(0.042)$ & $0.112(0.128)$ & $-0.003(-0.005)$ \\
$1995-96$ & $0.068(0.259)$ & $0.164(0.012)$ & $0.332(0.366)$ & $0.165(0.309)$ & $0.020(0.400)$ & $-0.049(0.268)$ \\
$1996-97$ & $-0.011(0.087)$ & $0.010(0.021)$ & $-0.152(-0.072)$ & $0.082(0.018)$ & $-0.048(-0.305)$ & $-0.113(0.214)$ \\
$1997-98$ & $0.138(0.032)$ & $0.174(0.208)$ & $-0.020(-0.150)$ & $0.0312(0.063)$ & $0.758(0.199)$ & $-0.002(-0.117)$ \\
$1998-99$ & $0.177(0.282)$ & $0.009(-0.064)$ & $-0.021(0.038)$ & $0.005(0.027)$ & $0.135(0.136)$ & $0.216(0.021)$ \\
$1999-00$ & $-0.014(-0.034)$ & $0.027(0.095)$ & $0.515(0.234)$ & $0.052(0.062)$ & $-0.019(-0.011)$ & $-0.003(-0.010)$ \\
$2000-01$ & $0.086(0.032)$ & $0.226(0.063)$ & $0.188(0.263)$ & $0.007(-0.005)$ & $-0.051(-0.024)$ & $-0.109(-0.133)$ \\
$2001-02$ & $-0.057(0.0189$ & $-0.115(-0.212)$ & $-0.097(-0.142)$ & $-0.023(-0.067)$ & $0.107(0.030)$ & $0.035(0.112)$ \\
$2002-03$ & $0.291(0.185)$ & $0.136(0.104)$ & $-0.089(0.017)$ & $0.006(-0.017)$ & $0.080(0.111)$ & $0.046(0.017)$ \\
$2003-04$ & $0.082(0.116)$ & $-0.067(-0.071)$ & $-0.018(-0.079)$ & $-0.039(-0.039)$ & $-0.031(0.086)$ & $0.120(0.000)$ \\
$2004-05$ & $0.093(0.063)$ & $0.088(-0.017)$ & $0.119(0.115)$ & $0.110(0.081)$ & $-0.022(-0.096)$ & $0.078(0.167)$ \\
$2005-06$ & $0.102(0.133)$ & $0.071(0.037)$ & $0.060(0.008)$ & $0.008(0.044)$ & $0.059(0.142)$ & $-0.007(-0.079)$ \\
$2006-07$ & $0.073(0.033)$ & $0.013(0.260)$ & $0.086(0.082)$ & $-0.083(0.031)$ & $0.102(0.108)$ & $0.142(1.137)$ \\
$2007-08$ & $0.336(0.335)$ & $0.212(0.247)$ & $0.088(0.273)$ & $0.038(0.051)$ & $0.124(0.081)$ & $0.097(0.140)$ \\
$2008-09$ & $0.169(0.093)$ & $0.166(-0.047)$ & $0.091(0.1029)$ & $0.219(-0.130)$ & $0.039(-0.033)$ & $0.064(0.144)$ \\
$2009-10$ & $-0.095(-0.072)$ & $0.467(0.280)$ & $-0.229(-0.296)$ & $-0.231(0.227)$ & $-0.050(-0.164)$ & $-0.056(0.072)$ \\
\hline \hline
\end{tabular}

Source: Calculated by the author using the data provided by Central Statistical Organization and Centre for Monitoring Indian Economy Pvt. Ltd. 
Table 9 continued

\begin{tabular}{lllllll}
\hline Year & NIC23 & NIC24 & NIC25 & NIC26 & NIC27 & NIC28 \\
\hline $1990-91$ & $0.183(0.117)$ & $0.073(0.129)$ & $0.437(0.278)$ & $0.415(0.035)$ & $0.180(0.251)$ & $0.251(0.187)$ \\
$1991-92$ & $0.173(0.292)$ & $0.224(0.059)$ & $0.159(0.206)$ & $-0.064(0.311)$ & $0.212(0.096)$ & $0.111(0.130)$ \\
$1992-93$ & $0.011(-0.111)$ & $-0.122(-0.191)$ & $0.226(-0.125)$ & $0.137(0.262)$ & $0.210(0.111)$ & $0.057(-0.047)$ \\
$1993-94$ & $0.098(-0.343)$ & $0.036(0.058)$ & $0.176(0.214)$ & $0.385(-0.322)$ & $-0.021(-0.059)$ & $-0.053(-0.030)$ \\
$1994-95$ & $-0.042(0.656)$ & $0.062(0.163)$ & $0.409(0.407)$ & $-0.073(0.280)$ & $0.063(0.056)$ & $-0.075(0.209)$ \\
$1995-96$ & $0.153(0.243)$ & $0.121(0.149)$ & $0.163(0.348)$ & $0.160(0.281)$ & $0.166(0.263)$ & $0.177(0.272)$ \\
$1996-97$ & $-0.096(0.055)$ & $0.035(-0.029)$ & $-0.072(0.034)$ & $-0.074(0.004)$ & $-0.051(0.051)$ & $0.004(0.064)$ \\
$1997-98$ & $0.025(-0.118)$ & $0.007(0.005)$ & $-0.076(-0.054)$ & $0.128(0.274)$ & $-0.011(0.107)$ & $0.038(-0.101)$ \\
$1998-99$ & $-0.104(-0.197)$ & $0.003(0.078)$ & $0.119(0.098)$ & $0.148(-0.125)$ & $-0.092(-0.080)$ & $-0.130(0.030)$ \\
$1999-00$ & $0.089(0.325)$ & $0.122(0.129)$ & $0.000(-0.151)$ & $0.134(-0.065)$ & $0.090(-0.053)$ & $0.029(-0.068)$ \\
$2000-01$ & $0.043(-0.019)$ & $0.088(-0.080)$ & $0.157(0.244)$ & $0.049(0.132)$ & $0.083(-0.081)$ & $-0.033(-0.017)$ \\
$2001-02$ & $0.003(-0.009)$ & $-0.049(-0.063)$ & $-0.045(-0.074)$ & $0.091(-0.064)$ & $0.003(0.086)$ & $-0.031(0.019)$ \\
$2002-03$ & $0.006(0.026)$ & $0.121(0.174)$ & $0.050(0.125)$ & $0.025(0.223)$ & $-0.212(-0.035)$ & $-0.026(-0.065)$ \\
$2003-04$ & $0.221(0.097)$ & $0.202(0.230)$ & $0.118(0.145)$ & $-0.192(-0.129)$ & $-0.015(-0.119)$ & $0.040(-0.066)$ \\
$2004-05$ & $0.015(0.150)$ & $0.206(0.329)$ & $0.257(0.291)$ & $0.173(-0.049)$ & $0.116(0.095)$ & $0.103(0.178)$ \\
$2005-06$ & $0.173(-0.049)$ & $-0.100(-0.152)$ & $0.387(0.177)$ & $-0.162(0.005)$ & $0.163(0.377)$ & $0.169(0.148)$ \\
$2006-07$ & $0.160(0.268)$ & $0.198(0.225)$ & $0.524(0.500)$ & $0.189(-0.008)$ & $0.262(0.311)$ & $0.157(0.722)$ \\
$2007-08$ & $0.159(0.274)$ & $0.111(0.144)$ & $0.343(0.393)$ & $-0.026(0.081)$ & $0.153(-0.028)$ & $0.054(0.178)$ \\
$2008-09$ & $0.022(0.024)$ & $-0.007(0.092)$ & $-0.082(-0.103)$ & $-0.384(0.222)$ & $-0.139(0.043)$ & $-0.126(-0.021)$ \\
$2009-10$ & $-0.077(-0.356)$ & $-0.106(-0.031)$ & $-0.235(-0.157)$ & $0.337(0.033)$ & $-0.313(-0.224)$ & $-0.196(-0.162)$ \\
\hline \hline
\end{tabular}

Source: Calculated by the author using the data provided by Central Statistical Organization and Centre for Monitoring Indian Economy Pvt. Ltd. 


\section{Appendix C. National Industrial Classification}

Table 10 provides the broad structure according to the latest available national industrial classification (NIC 2008). Since NIC 1987, the classification changed three times, in 1998, 2004 and 2008 respectively. In the paper, the data is classified according to NIC 2008 with the help of the respective concordance tables, available from Central Statistical Organization, Ministry of Statistics.

Table 10: National Industrial Classification (2-digit level)

\begin{tabular}{ll}
\hline NIC & Description \\
\hline NIC10 & Manufacture of food products \\
NIC11 & Manufacture of beverages \\
NIC12 & Manufacture of tobacco products \\
NIC13 & Manufacture of textiles \\
NIC14 & Manufacture of wearing apparel \\
NIC15 & Manufacture of leather and related products \\
NIC16 & Manufacture of wood and products of wood \\
NIC17 & Manufacture of paper and paper products \\
NIC18 & Printing and reproduction of recorded media \\
NIC19 & Manufacture of coke and refined petroleum products \\
NIC20 & Manufacture of chemicals and chemical products \\
NIC21 & Manufacture of pharmaceuticals, medicinal chemical and botanical products \\
NIC22 & Manufacture of rubber and plastics products \\
NIC23 & Manufacture of other non-metallic mineral products \\
NIC24 & Manufacture of basic metals \\
NIC25 & Manufacture of fabricated metal products, except machinery and equipment \\
NIC26 & Manufacture of computer, electronic and optical products \\
NIC27 & Manufacture of electrical equipment \\
NIC28 & Manufacture of machinery and equipment n.e.c \\
NIC29 & Manufacture of motor vehicles, trailers and semi-trailers \\
NIC30 & Manufacture of other transport equipment \\
NIC31 & Manufacture of Furniture \\
NIC32 & Other Manufacturing \\
\hline \hline
\end{tabular}

Note: NIC classification 2008 which corresponds to the ISIC rev 4. 


\section{References}

Aghion, P. and P. Howitt (1992). A model of growth through creative destruction. Econometrica 60, 323-351.

Amaral, L., S. Buldyrev, S. Havlin, P. Maass, M. Salinger, H. Stanley, and M. Stanley (1997). Scaling behavior in economics: The problem of quantifying company growth. Physica A $244(1), 1-24$.

Baily, M. N., C. Hulten, and D. Campbell (1992). Productivity dynamics in manufacturing establishments. Brookings Papers on Economic Activity: Microeconomics 4, 187-249.

Baldwin, J. R. (1998). The Dynamics of Industrial Competition: A North American Perspective. Cambridge University Press.

Bartelsman, E. J. and P. J. Dhrymes (1998). Productivity dynamics: U.S. manufacturing plants, 1972-1986. Journal of Productivity Analysis 9(1), 5-34.

Bartelsman, E. J. and M. Doms (2000). Understanding productivity: Lessons from longitudinal microdata. Journal of Economic Literature 38(2), 569-594.

Bernard, A. B. and B. J. Jensen (1995). Exporters, jobs, and wages in U.S. manufacturing: 1976-87. Brookings Papers on Economic Activity: Microeconomics 1995, 67-112.

Bernard, A. B. and B. J. Jensen (1999, February). Exceptional exporter performance: cause, effect, or both? Journal of International Economics 47(1), 1-25.

Bernard, A. B., J. B. Jensen, S. J. Redding, and P. K. Schott (2007, Summer). Firms in international trade. Journal of Economic Perspectives 21 (3), 105-130.

Bosworth, B., S. Collins, and A. Virmani (2007). Sources of growth in the indian economy. NBER Working Papers 12901, National Bureau of Economic Research, Inc.

Bottazzi, G., E. Cefis, and G. Dosi (2002). Corporate growth and industrial structure. some evidence from the Italian manufacturing industry. Industrial and Corporate Change 11, $705-723$.

Bottazzi, G., A. Coad, N. Jacoby, and A. Secchi (2011). Corporate growth and industrial dynamics: evidence from french manufacturing. Applied Economics 43(1), 103-116.

Bottazzi, G., G. Dosi, N. Jacoby, A. Secchi, and F. Tamagni (2010). Corporate performances and market selection: some comparative evidence. Industrial and Corporate Change 19(6), 1953-1996. 
Bottazzi, G., G. Dosi, and G. Rocchetti (2001, September). Modes of knowledge accumulation, entry regimes and patterns of industrial evolution. Industrial and Corporate Change 10(3), 609-38.

Bottazzi, G. and A. Secchi (2006). Explaining the distribution of firms growth rates. RAND Journal of Economics 37, 235-256.

Bottazzi, G. and A. Secchi (2011). A new class of asymmetric exponential power densities with applications to economics and finance. Industrial and Corporate Change 20(4), 9911030.

Del Monte, A. and E. Papagni (2003). R\&d and the growth of firms: empirical analysis of a panel of italian firms. Research policy 32(6), 1003-1014.

Dosi, G. (2007). Statistical regularities in the evolution of industries. a guide through some evidence and challenges for the theory. In F. Malerba and S. Brusoni (Eds.), Perspectives on Innovation. Cambridge University Press.

Dosi, G., M. Grazzi, C. Tomasi, and A. Zeli (2012). Turbulence underneath the big calm: what is happening behind the flat trend of productivity in Italy. Small Business Economics Journal 39(4), 1043-1067. DOI: 10.1007/s11187-011-9326-7.

Dosi, G., O. Marsili, L. Orsenigo, and R. Salvatore (1995). Learning, market selection and evolution of industrial structures. Small Business Economics 7(6), 411-36.

Dosi, G. and R. R. Nelson (2010). Technological change and industrial dynamics as evolutionary processes. In B. H. Hall and N. Rosenberg (Eds.), Handbook of the Economics of Innovation, Chapter 4. Elsevier: Amsterdam.

Duschl, M., A. Schimke, T. Brenner, and D. Luxen (2011). Firm growth and the spatial impact of geolocated external factors: Empirical evidence for german manufacturing firms. Technical report, Marburg Working Paper on Innovation and Space 03/11.

Geroski, P. A. (2002). The growth of firms in theory and in practice. In N. Foss and V. Mahnke (Eds.), Competence, Governance, and Entrepreneurship - Advances in Economic Strategy Research. Oxford University Press: Oxford and New York.

Goldberg, P. K., A. K. Khandelwal, N. Pavcnik, and P. Topalova (2010, November). Imported intermediate inputs and domestic product growth: Evidence from india. The Quarterly Journal of Economics 125(4), 1727-1767. 
Government of India (2011). Faster, Sustainable and More Inclusive Growth. An Approach to the Twelfth Five Year Plan (2012-2017). Planning Commission.

Grazzi, M. (2012). Export and firm performance: Evidence on productivity and profitability of Italian companies. Journal of Industry, Competition and Trade 12(4), 413-444.

Haidar, J. (2012). Trade and productivity: self-selection or learning-by-exporting in india. Economic Modelling 29(5), 1766-1773.

Hall, B. H. (1987). The relationship between firm size and firm growth in the us manufacturing sector. Journal of Industrial Economics 35(4), 583-606.

Hall, B. H. and J. Mairesse (1995, January). Exploring the relationship between R\&D and productivity in french manufacturing firms. Journal of Econometrics 65(1), 263-293.

Jensen, B. J. and R. H. McGuckin (1997). Firm performance and evolution: Empirical regularities in the us microdata. Industrial and Corporate Change 6, 25-47.

Koenker, R. and G. W. Basset (1978). Regression quantiles. Econometrica 46, 33-50.

Koenker, R. and K. Hallock (2001). Quantile regression: An introduction. Journal of Economic Perspectives 15(4), 43-56.

Lefebvre, E., L. Lefebvre, and M. Bourgault (1998). R\&d-related capabilities as determinants of export performance. Small Business Economics 10(4), 365-377.

Lichtenberg, F. and D. Siegel (1991). The impact of r\&d investment on productivity-new evidence using linked r\&d-lrd data. Economic Inquiry 29(2), 203-229.

Nelson, R. R. and S. G. Winter (1982). An Evolutionary Theory of Economic Change. The Belknap Press of Harvard University Press: Cambridge, MA.

Reichstein, T. and M. Jensen (2005). Firm size and firm growth rate distributionsthe case of denmark. Industrial and Corporate Change 14(6), 1145-1166.

Roberts, M. J. and J. R. Tybout (1997, September). The decision to export in Colombia: An empirical model of entry with sunk costs. American Economic Review 87(4), 545-64.

Rodrik, D. and A. Subramanian (2005). From "Hindu growth" to productivity surge: The mystery of the Indian growth transition. IMF Staff Papers, 193-228.

Silverberg, G., G. Dosi, and L. Orsenigo (1988). Innovation, diversity and diffusion: A selforganisation model. Economic Journal 98, 1032-1054. 
Silverberg, G. and B. Verspagen (1994). Learning, innovation and economic growth: A longrun model of industrial dynamics. Industrial and Corporate Change 3(1), 199-223.

Stanley, M., L. Amaral, S. Buldyrev, S. Havlin, H. Leschhorn, P. Maass, M. Salinger, and H. Stanley (1996). Scaling behaviour in the growth of companies. Nature 379, 804-806.

Topalova, P. and A. Khandelwal (2011, August). Trade liberalization and firm productivity: The case of India. The Review of Economics and Statistics 93(3), 995-1009.

Virmani, A. and D. Hashim (2009). Factor employment, sources and sustainability of output growth: Analysis of indian manufacturing. Ministry of Finance, Government of India, Working Paper (3), 21.

Wagner, J. (2002, October). The causal effects of exports on firm size and labor productivity: first evidence from a matching approach. Economics Letters 77(2), 287-292.

Winter, S. G. (1984). Schumpeterian competition under alternative technological regimes. Journal of Economic Behavior and Organization 5, 287-320.

Winter, S. G., Y. M. Kaniovski, and G. Dosi (2000, September). Modeling industrial dynamics with innovative entrants. Structural Change and Economic Dynamics 11(3), 255-293. 